ISSN No. 0974-035X

An indexed refereed \& peer-reviewed journal of higher education

Towards Excellence

UGC-HUMAN RESOURCE DEVELOPMENT CENTRE

Gujarat University, Ahmedabad-380009, Gujarat, India

\title{
INDIAN NATIONAL POLICY ON EDUCATION 2020
}

\section{Prof. Dr Jagdish Joshi \\ Dr Parin Somani}

\begin{abstract}
The Education system has always been a fundamental part of the economic development of any country. It is utilised to equip individuals to face the future with the skills to achieve their full potential. Within India, the focus of education has been to improve the literacy rate of individuals within the country and promote economic growth within an equitable, just society. The increase of globalisation has enabled the establishment of new policies and strategies to drive educational reforms. The government of India aim to ensure every individual has access to education, paving the way to a sustainable future. This has been illustrated through Prime Minister Narender Modi's decision to rename the Ministry of Human Resources and Development to the Ministry of Education accompanied by a new policy the 'National Education Policy 2020' (NEP 2020), illustrating commitment to the education system within India.
\end{abstract}

Keywords: NEP2020, GOI Education, National Education Policy, NEP Goals

\section{Introduction}

Education is vital within an ever-changing world, where there are constantly new technological advancements in different subject areas. There is a requirement for educated skilled workforces, consisting of multidisciplinary abilities. There are changes in global warming and unpredicted pandemics, there is a growing demand for educated individuals within different subject areas. Over the next ten years it is anticipated that India will incur the highest population of young people in the world (India, 2020). Therefore, there is a requirement to provide educational opportunities for the country's future sustainability. In 2015, the agenda for sustainable development mentioned that it seeks to ensure inclusive and equitable quality education and promote lifelong learning opportunities for all by 2030 under goal four (Nations, 2017). With such rapid change it has been identified that education should move towards critical thinking and problem-solving, creativity and adapting to new innovative material, in 
these ever-changing fields opposed to content related education only. It has also been identified that pedagogy must be more enjoyable with a holistic, experimental, integrated, flexible, enquiry driven, discovery orientated, discussion-based and learner centred (India, 2020). By including a variety subject areas which not only include mathematics, science and technology but also incorporate arts, humanities, crafts, sports, games and fitness, culture, language, literature and values, it enables the development of multiple aspects of learners capabilities preparing them for employment. Simultaneously, education should build ethical, compassionate, rational and caring characteristics building character forming a just society, despite social, economic or background.

\section{History}

The initial National Education Policy (NEP) was framed and modified in 1986 and1992 respectively. Since 2014, PM Modi created a new education policy stated in the Bharatiya Janata Party manifesto during the Lok Sabah elections. He ensured this was implemented and began the consultation process in 2015, enduring many interventions. On the 29th of June 2020, the NEP 2020 was approved by the Union Cabinet of India replacing the previous 1986 policy.

\section{Goal of the NEP 2020}

The goal of the NEP 2020 is to provide a framework enabling the development of good human being's in India. Citizens that have the tools and abilities to implement a rational thought process, with ethical values and principles, building towards an equitable, all-inclusive and pluralistic society (India, 2020). NEP 2020, is a framework that aims to transform the education system by 2035 through its comprehensive elementary to higher educational agenda, including vocational training in urban and rural India (Jebaraj, 2020). Its aims to expand higher education to $50 \%$ of high school students by 2035 . It emphasises that there is no pressure to study a specific language, however the medium of instruction will continue to be in English (Vishnoi, 2020). Through knowledge, wisdom and truth the educational policy allows students to learn and aims to prepare an individual for life beyond school for liberation of oneself, stemming from the Indian thought and philosophy (India, 2020). It aims to re-establish teachers, help to shape the young Indian generations through autonomy, accountability, respect and dignity. While, providing a quality educational system accessible to every student despite where they reside. There is a focus on the disadvantaged, marginalised and underrepresented 
groups who through NEP 2020 are provided opportunities to progress within the educational system. It has been proven that through education, better economic and social mobility can be resumed with inclusion and equality as a result of acquiring knowledge.

\section{Fundamental principles}

The NEP 2020 contains guidelines that help educational systems and individual institutions to comply in unison and adhere to fundamental principles which include identifying, recognising and fostering the unique capabilities of each learner. This enables students to grow their holistic development in academic subjects. Foundational literacy and numeracy by grade three is now a priority. There is flexibility for students to identify their talents and interests and then choose a desirable future. Hard separations between subjects have been eliminated the segregation of hierarchies associated with different learning areas. In order to ensure unity and integration of all knowledge, holistic education across sciences a multidisciplinary approach has been adopted. There is an emphasis on conceptual understanding in comparison to learning for exams. Importance is given to critical and creative thinking with the view of encouragement given to creativity and logical decision-making. Also learning ethics and human and constitutional values, promoting multilingualism and the power of language, life skills, regular formative assessment for learning in comparison to summitted assessment (India, 2020). Simultaneously, the extensive use of technology is now used, removing language barriers. A respect for diversity and local context is illustrated through the curriculum, pedagogy and policies. There should be full equality and inclusion and synergy in the curriculum across all levels of education. The regularity framework to ensure transparency integrity and the use of positions resources. Outstanding research and continuous review, a rootedness and pride in India should be taught and knowing that education is a public service and every child has the right to education. There is also a substantial investment in strong, vibrant public education system. Through these principles it is believed that students will be able to deliver to the knowledge, skills and values that will enable them to become responsible, committed to human rights, develop a sustainable living, contribute to global well-being and become an all-round global citizen (India, 2020).

\section{Policy changes}


Towards Excellence: An Indexed, Refereed \& Peer Reviewed Journal of Higher Education /

Prof. Dr. Jagdish Joshi \& Dr. Parin Somani/ Page 453-460

PM Modi has made many changes to the NEP 2020 for the betterment of national citizens. He aims to increase educational funding to 6\% GDP from 4\% soon (Upadhyay, 2020).

\section{Higher education}

Great importance is given to higher education within India, which is why an independent Higher Education Council of India (HECI) is going to be set up. The HECI will regulate higher education to increase gross enrolment ratio. It will be the governing body that will be replacing the current University Grants Commission, All India Council of Technical Education, National Assessment and Accreditation Council. HECI will now comprise of four verticals: 1. National Higher Education Regulatory Counsel solely to regulate higher education, excluding legal and medical education. 2. National accreditation counsel which is a matter accrediting body. 3 . Replace the current National Council for Teacher Education, All India Counsel for Technical Education and the University Grants Commission, with the Higher Education Grants Commission. 4. General Education Council will be used to frame graduate attributes predominantly the learning outcomes that are expected, and are responsible for creating a framework for the National Higher Education Qualification Framework (Kumar P. , 2020). The current National Council for Teacher Education will then be under the General Education Council as a Professional Standard Setting Body (PSSB) (Shukla, 2020). The professional councils like the Veterinary Council of India, the Indian Council of Agricultural Research, the Council of Architecture and National Council of Vocational Education Training will all be under other PSSB (Kumari, 2020).

Admissions and entrance exams to universities throughout the country will now occur through the governing body National Testing Agency in addition to the joint entrance examinationmain (JEE-Main), previously known as the all India engineering entrance exam and The National Eligibility cum Entrance Exam for undergraduate students which was previously known as the All India Pre-Medical Test (Desk, 2020).

Changes implemented the NEP 2020 within higher education aims to provide quality in universities and colleges throughout India. Improving human and societal well-being, ensuring that India is the democratic, cultured socially conscious, equal, just nation to improve human and societal well-being. It is higher education that enables progression towards achieving a knowledgeable, economic society (India, 2020). The policy includes multiple exit options for 
learner upon entering an undergraduate multidisciplinary bachelor's degree program (Srinivasan, 2020). Certificates will be available within vocational and professional areas, presented after one year of studying and completing the course. Then at two years upon course completion a diploma will be presented and upon completing a three-year program a bachelor's degree will be awarded (Kumar P. , 2020). PM Modi has changed the Master of Philosophy (MPhil) degree courses to imitate western models (Bhura, 2020).

With the increased use of technology, particularly as a result of the pandemic, the NEP 2020 has stated that the Indian Institute of Technology will implement changes regarding the diversity of learning (Srinivasan, 2020). Along with existing E-learning platforms like SWAYAM, to help teachers to monitor the progress of the students with using video and audio platforms DIKSHA will also be rolled out.

PM Modi has proposed strategies to incorporate International education within India. International universities can now establish a campus within India as PM Modi quoted that he will allow entry of the top world renowned universities to open campuses in India (Kumar M. , 2020). This is the way of increasing education and strengthening economy especially with the impact of the coronavirus pandemic. This strategy has been implemented, as approximately 750,000 Indian student's travel outside of India to study, spending billions of dollars outside the country.

Another change is that there will be fixed fees for private and public universities (Kumar M. , 2020). This is implemented with the aim of combating commercialisation of higher education. Similar auditing standards and disclosures as non-profit entities will be adhered to, with any surplus financial resources re-invested within the educational sector.

Many changes have been made for teachers, to possess the precise tools required to teach the students who are the future of the country. By 2030, a minimum educational teacher requirement, will consist of a four-year Bachelor of Education Course. The teacher recruitment process will become more robust and transparent. It is proposed that by 2021 there will be a National Curriculum Framework for Teacher Education devised by the National Council for Teacher Education. By 2022 the National Professional Standards for Teachers will make sure 
every student, will be taught by well qualified and trained educators, possessing passion, motivation and knowledge to help their students.

Much legislative intervention within the NEP 2020 has allowed new institutes, concepts and bodies to be formed. PM Modi himself will be heading the National Education Commission (Upadhyay, 2020). The Academic Bank of Credit, which is a digital storage of credit, will be utilised when a student wishes to resume their studying after a break, without having to repeat the year. There are also plans to improve innovation and research through the National Research Foundation (Shukla, 2020). PM Modi has not missed the underrepresented groups in disadvantaged regions, as he has set up special education zones to focus attention on their needs. A gender inclusion fund is also proposed, aiming to help the nation through educating females and transgender children (Pandit, 2020). Through the immense technology that is being currently utilised PM Modi has set up a National Educational Technology Forum to enable dialogue to improve technology usage and facilitate learning.

\section{Conclusion}

PM Modi has taken steps to implement his vision to transform India through providing a higher quality of education for every individual, building a sustainable, positive, equitable knowledge society within the nation, to ensure the formation of true global citizens. He is looking ahead and implementing change that may not be desirable to all, however, it is only through administering NEP 2020 positively that we will be able to see positive change in the future. 
Towards Excellence: An Indexed, Refereed \& Peer Reviewed Journal of Higher Education / Prof. Dr. Jagdish Joshi \& Dr. Parin Somani/ Page 453-460

\section{References}

Bhura, S. (2020, 07 20). In defence of MPhil: Why the degree should not be discontinued. Retrieved from The week: https://www.theweek.in/news/india/2020/07/30/in-defenceof-mphil-why-the-degree-should-not-be-discontinued.html

Desk, E. (2020, 07 29). National Education Policy: NTA to conduct common entrance exam for higher education institutes. Retrieved from Indian express: https://indianexpress.com/article/education/nta-to-offer-common-entrance-exam-forhigher-education-institutes-nta-ac-in-6529437/

India, G. o. (2020). National Education Policy 2020. India: Ministry of Human Resource Development.

Jebaraj, P. (2020). The Hindu Explains | What has the National Education Policy 2020 proposed. The Hindu.

Krishna, A. (2020, 07 29). NEP 2020 Highlights: School And Higher Education. Retrieved from NDTV: https://www.ndtv.com/education/nep-2020-highlights-school-andhigher-education

Kumar, M. (2020, 07 29). India opens door for foreign universities under new education policy. Retrieved from World news: https://www.reuters.com/article/us-india-educationidUSKCN24U2K6

Kumar, P. (2020, 07 31). New Education Policy: Five big changes in school, higher education explained. Retrieved from Livemint: https://www.livemint.com/education/news/neweducation-policy-five-big-changes-in-school-higher-education-explained11596098141333.html

Kumari, A. (2020, 07 30). National Education Policy 2020: UGC, AICTE, NAAC To Be Merged In A New Body. Retrieved from NDTV: https://www.ndtv.com/education/national-education-policy-2020-ugc-aicte-naac-bemerged-in-new-body

Nations, U. (2017). Voluntary National Review Report on Implementation of Sustainable Development Goals. New York: United Nations. 
Towards Excellence: An Indexed, Refereed \& Peer Reviewed Journal of Higher Education / Prof. Dr. Jagdish Joshi \& Dr. Parin Somani/ Page 453-460

Pandit, A. (2020, 07 30). Gender Inclusion Fund, Spl Edu Zones in policy . Retrieved from Times of India: https://www.livemint.com/education/news/4-year-bed-degree-to-beminimum-qualification-for-teaching-by-2030-says-new-nep-11596100700209.html

PTI. (2020, 30 07). 4-year BEd degree to be minimum qualification for teaching by 2030, says new NEP. Retrieved from Livemint: https://www.livemint.com/education/news/4year-bed-degree-to-be-minimum-qualification-for-teaching-by-2030-says-new-nep11596100700209.html

Shukla, A. (2020, 07 29). New Education Policy 2020: NEP moots professional standards for teachers. Retrieved from Hindustan Times: https://www.hindustantimes.com/education/new-education-policy-2020-nep-mootsprofessional-standards-for-teachers/story-F7IvmL73MfFLnGCn5EWBLK.html

Srinivasan, C. (2020, 07 29). Teaching In Mother Tongue Till Class 5: 10 Points On New National Education Policy . Retrieved from NDTV: https://www.ndtv.com/indianews/national-education-policy-nep-2020-mother-tongue-till-class-5-10-points-onnational-education-policy-2020-2270926

Upadhayay, D. (2020, 07 29). New school education policy approved: Grading system, more choice of subjects. Retrieved from Livemint: https://www.livemint.com/education/news/new-school-education-policy-gradingsystem-more-choice-of-subjects-11596001769379.html

Upadhyay, D. (2020, 07 29). Govt approves plan to boost state spending on education to 6\% of GDP. Retrieved from Live mint: https://www.livemint.com/education/news/govtapproves-plan-to-boost-state-spending-on-education-to-6-of-gdp11596024998889.html

Vishnoi, A. (2020). No switch in instruction medium from English to regional languages with NEP '20: HRD. The Economic Times.

\section{Prof. Dr Jagdish Joshi UGC-Human Resource Development Centre (UGC-ASC), Gujarat University, Ahmedabad \& Dr Parin Somani, UK}

